\title{
FACTORS OF PERSONAL MOTIVATION IN ERIC RAMIRO KIRSTEN'S MOVIE SCRIPT MIDNIGHT SUN
}

\author{
Nanda Herliana, Andang Suhendi \\ Faculty of Literature, Universitas Islam Sumatera Utara \\ Medan, Indonesia \\ e-mail: nandaherliana19@gmail.com
}

Received: 2021-10-15

Accepted: 2021-11-21

\begin{abstract}
This study is conducted to analyze the factors of personal motivation in Midnight Sun movie written by Eric Kirsten. This study applies qualitative descriptive method since the process and the result of the research are accomplished descriptively. Then, the theory proposed by McClelland is used in this study. He mentions two types of factors of personal motivation. The factors include internal and external. This study is focused only on internal factors. It is stated that five factors belong to internal factors of motivation. After having analyzed those factors in the movie, only four factors are found in the analysis. They are need, hope, responsibility, self-esteem and achievement, while, job satisfaction is not found in the movie. The four internal factors happen within the protagonist himself. These factors emerge from the characters' personal motivation. By the internal factors, the protagonist can make his dream come true. In conclusion, the result of this study shows that to realize dream and to avoid adversity, we must have a motivation to make it happen.
\end{abstract}

Keywords: hope, responsibility, self-esteem, achievement, personal motivation

\section{Introduction}

Literary work is a product of the soul's wandering and intellectuality of an author destined through the various processes that underline it. Literary work means an essay that refers to the values of goodness written in general language about human, social, and intellectual problems in a unique way. According to Hurlock (1980: 74-75) a literary work will provide different information for different readers. Literary readers are allowed to interpret literary text according to their own insights. Literature is a creative activity, a work of art (Wellek and Waren, 2016: 3).

This study discusses one of from literary works, Drama. The Drama has been performed in the film. The film as the object of analysis is Midnight Sun. Drama is a mode of fictional representation through dialogue and performance. It is one of the literary genres, which is an imitation of some action. Drama is also a type of a play written for teather, television, radio, and film. Dramas depend heavily on spoken dialogue to keep the audience informed about the characters feelings, personalities, motivations, and plans. Since the audience sees characters in a drama living out their experiences without any explanatory comments from the author, playwrights often create dramatic tension by having their characters deliver soliloquies and asides. 
Concerning the spoken dialogue in Midnight Sun, the researcher analyses the character's motivation which is unique to be discussed because motivation drives people to keep going even in the face of set-backs, to take up opportunities, and to show commitment to what they want to achieve. This page explains more about this essential area, part of emotional entelligence.

According to Sadirman (2011: 75), motivation is the overall driving force within students that gives rise to learning activities, which ensures the continuity of learning activities and which gives direction to learning activities, so that the goals desired by the learning subject can be achieved.

Alma (2013: 89) says that motivation is the willingness to do something. While motive is a need, desire, impulse or impulse. A person's motivation depends on the strenght of his motive. Motivation affects the changes that occur in a person that appears in changes in attitudes and feelings and emotions, so that can encourage someone to do an action due to a desire or a goal that must be achieved. Without the presence of motivation, a person will not be moved to start behavior because there is no determination to reach his target. The Drama "Circus Midnight Sun" was chosen as the subject of discussion in this research can be described by relevant reasons. The reason behind the researchers in conducting this research is because in the drama by Eric Kirsten is a drama that has its own uniqueness.

The motivation theory used in this study is taken from McClelland in Lili and Nasution (2005). The theory refers to a self-actualized being or personal motivation which is implemented in personal needs. Those needs are physiological, safety, love, esteem, and self-actualization. In which the factors are generally owned by humans, namely internal or personal motivation and external motivation. Internal or personal motivation is a motivational factor that comes from within the individual. The internal factors includes needs, hope, job satisfaction, responsibility, self-esteem and achievement. These factors are focused on this study.

External is a factor that comes from outside the individual. Internal motivation has five factors, namely individual perceptions of themselves, self-esteem and achievement, expectations, needs, and job satisfaction. External motivation has four factors, namely the work group, the type and nature of the job, the environmental situation, and the reward system. Unfortunately, these external factors are not discussed in this study.

\section{Literature Review}

\subsection{Motivation}

Human motivation is a complex and well studied field that has broad roots in a diverse collection of academic disciplines including psychology, sociology, education, political science, and economics. In simplified terms, motivation can be defined as what causes people to behave as they do (Denhardt, 2008: 146). Unfortunately, this simple definition hides the dynamic intricacies of the motivation literature.

There tends to be a general consensus as to the definition of motivation which reflects that (1) motivation is goal directed, (2) motivation outlines the achievement and pursuit of goals and (3) motivation is environmentally dependent (Campbell and Pritchard, 1976: 156). They defines motivation as being the set of psychological processes that cause the initiation, direction, intensity, and persistence of behavior.

Because motivation is so difficult to define, it may help in determining what motivation is not. Denhardt (2008) outlines four examples. Motivation is not (1) directly 
observable, (2) the same as satisfaction, (3) always conscious, and (4) directly controllable.

Motivation is not directly observable. "Motivation is an internal state that causes people to behave in a particular way to accomplish particular goals and purposes. It is possible to observe the outward manifestations of motivation but not motivation itself (Denhardt, 2008: 147). For instance, the acquisition of money may be an extrinsic motivator, but it is simply the manifestation of the internal drive to meet intrinsic needs like purchasing food, paying rent for shelter, or acquiring high social status.

Motivation is not always conscious. Unconscious motivation is quite central to Sigmund Freud's theories of human behavior. Freud posits that most human behavior is the result of unconscious repressed memories, impulses, and desires that influence and drive many human behaviors Alma (2013). A manifestation of this idea is the "Freudian slip" where an accidental word slip actually betrays true internal feelings and intentions.

Motivation is not directly controllable. "Motivation is not something that people do to others. Motivation occurs within people's minds and hearts. Managers can influence the motivational process, but they cannot control it" Denhardt (2008: 147)

The purpose of this paper is to give a detailed review of the literature of motivation in a thematic and quasi-chronological fashion. This will permit the reader to gain a thorough understanding of the many facets of motivation theories in modern literature. A cursory view of the literature will show that there are two central categories of motivation theories: content and process theories.

Content theories are centered around the assumption that individuals all share a similar set of human needs and that we are all motivated to satisfy those needs. Process theories are centered around the rational cognitive process and say that while most people may have similar needs, the importance and placement of those needs is different for everyone; that it is something highly subjective.

Furthermore, the concept of the need for achievement is abbreviated with a symbol which later became very famous, namely: n-Ach. According to Malone and Lepper (1987) to make a job successful, the most important thing is the attitude towards the job. He has conducted extensive research on motivation in relation to the need for achievement since the late 1990s. The results of his research show that the ups and downs of countries and their cultures are closely related to changes in the need for achievement.

According to McClelland (2005) as quoted in the Scientific Journal of Psychology and Organization "The Influence of Achievement Orientation Leadership Behavior Patterns on Achievement Motivation and Organizational Culture Application" defines achievement motivation as an encouragement from within a person to perform an activity or task as well as possible in order to achieve achievement with the predicate commendable. This is in accordance with the opinion of Johnson et al. who argues that "achievement motive is impetus to do well relative to some standard of excellence."

Understanding achievement motivation can be interpreted as the impetus that exists within a person to carry out activities as well as possible in order to achieve organizational goals Mangkunegara (2008).

McClelland (2005: 67) verifies the theory of the need to get achievement or Need for Achievement N.Ach which states that motivation varies, according to the strength of a person's need for achievement. McClelland (2005) states that a person's behavior arises because of the influence of his needs. In McClelland's concept of 
Factors of Personal Motivation in Eric Ramiro Kirsten's Movie Script Midnight Sun, Nanda Herliana, Andang Suhendi

motivation. According to Latifah (2012) there are three basic needs in a person that drive behavior include need for achievement, need for affiliate, and need for Power.

\subsection{Types of Motivation}

By looking deeper into the multiple theories of motivation, one will find that there are two basic types of motivation i.e., intrinsic and extrinsic motivation. Intrinsically motivated behaviors are seen when there is no other apparent reward expect the activity itself. Malone and Lepper (1987) have defined it as "what people will do without external inducement. Examples of intrinsic motivation are hunger, a sense of duty, altruism, and a desire to feel appreciated. Extrinsically motivated behaviors are those where the controlling mechanism is easily seen. Examples of extrinsic motivation are money, rules and laws, and the physical environment.

Alma (2013) states that intrinsically motivated behaviors are innate and can result in creativity, flexibility, and spontaneity while extrinsically motivated behaviors are generally done as consequence of pressure and result in low self-esteem and anxiety. However, even the mere identification of intrinsic/extrinsic behaviors has been a topic of debate. Despite this, the distinction between intrinsic and extrinsic motivation is an important one given their impact upon each other.

There has been much research into the effects that intrinsic and extrinsic motivation have upon each other, especially in the field of education. It has been found that many students do not find studying to be intrinsically rewarding and that extrinsic motivation has the exact opposite effect on student achievement than is desired (Lepper \& Hodell, 1989). In fact, Lepper \& Hodell have shown that when individuals are asked to complete a task, mere verbal praise after successfully completing the task increases intrinsic motivation. Contrary to popular belief, the use of expected extrinsic rewards for completing the task actually produces a negative motivational effect for future task completion once the reward is removed. However, Cameron and Pierce also found that reinforcement, unlike reward, does not harm intrinsic motivation Cameron \& Pierce (1994).

Taking these findings into the realm of motivation in organizations, we must now be cognizant of the fact that by simply applying extrinsic motivation methods without also addressing intrinsic factors, managers could be doing more harm than good. Also, managers must understand that by simply rewarding workers through extrinsic means, they are actually perpetuating a destructive cycle of continual reward and decreased intrinsic motivation. It is important to keep this in mind as we cover the myriad of theories and needs outlined below.

\subsection{Content Theories of Motivation}

Shortly after Fritz Roethisberger published his 1941 book Management and Morale, outlining in detail the Hawthorn studies, Abraham Maslow published "A Theory of Human Motivation" in 1943. Maslow is considered the father of needs basedmotivation theory and his theory is "one of the best-known and most widely cited works on motivation" (Lili and Nasution, 2005).

Maslow (1946) proposes a five level hierarchy of needs which he outlined as necessary for the achievement of a completely satisfied individual; or in his terms, a self actualized being. Those needs are: physiological, safety, love, esteem, and selfactualization. 
Physiological needs can be described as the most basic of human needs; those needed for human survival. These include breathing, water, food, and shelter. Safety needs are those needs which create stability and predictability in our lives: personal and financial security, health and well-being, and employment and access to resources. Love/belonging needs are centered around social interactions and interpersonal relationships: friendship, family, and intimacy. Esteem needs reflect our desires for respect, self-esteem and the need to belong McClelland in Lili and Nasution (2005).

Finally, self-actualization is the state which the individual achieves when all other needs have been meet. Maslow identifies fifteen attributes that self-actualized individuals experience, and thus the exact definition of being "self-actualized" is difficult to summarize. Some of the characteristics include: the acceptance of self, others and nature; spontaneity; autonomy independent of culture and environment; and the mystic experience.

Feelings of limitless horizons opening up to the vision, the feeling of being simultaneously more powerful and also more helpless than one ever was before, the feeling of ecstasy and wonder and awe, the loss of placement in time and space with, finally, the conviction that something extremely important and valuable had happened, so that the subject was to some extent transformed and strengthened even in his daily life by such experiences. Each need, or level, is fulfilled in sequence and serves as motivation until all the needs of the individual are meet in self-actualization. While Maslow emphasized that individuals will generally be motivated to seek each need in the order described, he also stated that the order of his hierarchy is "not nearly as rigid as we may have implied" and that in some individuals will seek needs in different order.

It is important to remember that McClelland in Lili and Nasution (2005) realized that his hierarchy of needs was more theoretical than normative; the present theory then must be considered to be a suggested program or framework for future research and must stand or fall, not so much on facts available or evidence presented, as upon researches yet to be done, researches suggested perhaps, by the questions raised in this paper.

\subsection{Factors of Personal Motivation}

A person's self-motivation can be influenced by several factors, according to McClelland (2005):

\subsubsection{Internal Factor}

Internal factors are personal motivational factors that come from within the individual. This motivation arises because of a person's desire to excel and be responsible for his or her life. Some of the things that include personal internal factors, are:

a. Need, to most psychologists, is a psychological feature that arouses an organism to action toward a goal, giving purpose and direction to behavior. Human needs are commonly used to refer to the drivers of peoples' actions, the motives behind human behavior. They take the elements that contribute to achieving the goal of a good life such as jobs, income, health care, status as the requirements or needs for the realization of the goal.

b. Hope is associated with many positive outcomes, including greater happiness, better academic achievement and even lowered risk of death. It is necessary ingredient for getting through tough times, of course, but also for meeting everyday goals. 
c. Job satisfaction tends to achieve higher productivity. Increased Profits - Keeping employees safe and satisfied can lead to higher sales, lower costs and a stronger bottom line.

d. Responsibility means being dependable, keeping promises and honoring our commitments. It is accepting the consequences for what we say and do. It also means developing our potential.

e. Self-esteem and achievement refer to an individual's sense of his or her value or worth, or the extent to which a person values, approves of, appreciates, prizes, or likes him or herself.

\subsubsection{External Factors}

External personal motivational factors are motivational factors that come from outside the individual. This motivation arises because of the role and influence from outside, such as companies or organizations, which can change the behavior of individuals in their lives. Some of the things that include external factors, namely:

1. Type and nature of work

2. Interpersonal relations

3. Team work

4. Working conditions

5. Work safety and security

\section{Research Method}

This study uses the theory of repentance proposed by McClelland in Lili and Nasution (2005) to find the factors of personal motivation in the movie script Midnight Sun. Then, the qualitative descriptive method was applied to analyze the data. According to Creswell (2013) that qualitative research begins with assumptions and the use of interpretive or theoretical frameworks that inform the study of research problems addressing the meaning individuals of groups ascribe to a social or human problem.

\section{Discussion}

The analysis of this study focuses on internal factors of personal motivation Midnight Sun by Eric Kirsten. The analysis includes need, hope, responsible, and selfesteem. Each part is explained as follows:

\subsection{Need}

A need is something that is necessary for an organism to live a healthy life. Needs are distinguished from wants. In other words, a need is something required for a safe, stable and healthy life e.g. air, water, food, land, shelter while a want is a desire, wish or aspiration. As explained in chapter II 2.4.1 part a, it causes people definitely have desires in life. In the film, Midnight Sun need occurs when Charlie wants to take part in the swimming competition and win the competition. So, he can get a scholarship to Berkeley. Because this is a dream of Charlie. So in order to be able to realize his dream, Charlie trains swimming in earnest.

"I could they just take your scholarship away? Well, I had to have surgery. And they did not think I could ever swim sgain. And no more scholarship meant no more Berkeley. (Kirsten, 2018: 40 - 41). 
The quotation above describes about Charlie who wants to follow a swimming competition in order to get a scholarship, but he suffered a injury to his shoulder which caused him to lose confidence by the Berkeley coach. Due to the Berkeley coach thought that Charlie did not swim because he had injured in his shoulder. That makes Charlie not excited. Even though Charlie has been training hard so that he can win a swimming competition and get a scholarship to Berkeley.

"So, what are you gonna do this year, now that you are not going to

Berkeley? Well, I'm first get a new truck. And then I'm gonna drive acrosss the country." (Kirsten, 2018: 43).

The quotation above explains that Katie asks Charlie what he will do for he does not go to Berkeley. Then Charlie explained that he needed a new truck so he could travel around the country in his new truck. Because Charlie felt that he had been in the column all his life, to practice swimming seriously but what happened he had an injury to his body and that prevented Charlie from participating in the swimming competition. So Charlie needs a new truck to drive across the country.

\subsection{Hope}

In the film Midnight Sun, hope occurs after suffering from an injury to his shoulder, which prevents him from participating in swimming competitions. Charlie wished that he could take Katie around the harbor and enjoy the sunset together, because Charlie thought he could not take part in the swimming competition so he had plenty of time to ask Katie out. And then the Berkeley coach contacted Charlie that one of the participants was out and Charlie could replace him. So Charlie hopes to reach the total before the competition starts and win the competition so he can continue his scholarship to Berkeley.

"You wanna see something cool? Ta-da! This is yours? No. But it is something I'm taking care of for the summer. It is a Jepersen 53. Wow. One fo these days we could take her for a sail around the harbor, we can watch the sunset. That's sounds perfect."

(Kirsten, 2018: 43).

Charlie had brought Katie to see the ship that Charlie was taking care of. And Katie was amazed at the sight of the ship. Since Charlie could not take part in the swimming competition, so Charlie hope he and Katie could sail with Katie around the harbor and watch the sunset. Charlie does not want to be sad about not being able to take part in the swimming competition, so he looks for other things to do by taking care of someone else's ship.

"Are you okay? The Berkeley coach called my house the other Night.

Really? Yeah, I mean, I guess one of the other swimmers Transferred out and another spot opened up. Wow. That is so crazy."

(Kirsten, 2018: 49-50).

It is described that Charlie tells Katie that the Berkeley coach calls her home. The reason the Berkeley coach called was because one of the swimmers had transferred out, so Charlie gets hope for a swimming competition and proves that he deserves to be a winner in a swimming competition and get a scholarship to Berkeley.

"Wait, where is this place? We're here. Charlie, what is this place? 
Factors of Personal Motivation in Eric Ramiro Kirsten's Movie Script Midnight Sun, Nanda Herliana, Andang Suhendi

It's your surprise. Charlie, my man. I thought Seattle was my surprise." (Kirsten, 2018: 39).

The above part illustrates that Charlie asks Katie to go to a party because Katie never knew what a party was like. And Katie wished she could come to the party and experience what it was like. So Charlie asked Katie to show her what a party was like. Katie never goes to parties because her father always forbids her to go out, the reason Katie's father does this is so that Katie avoids socializing that can ruin her. And because of Katie's illness, Katie does not have many friends to play with. Katie only has one friend. So Katie can only play guitar at home, and write in her diary. That is all she does every day. When Charlie asked her to go to a party, Katie was happy to know how the party was and she did not forget the moment.

"You know, you have to do something with your music. No, I could not. You have to, Katie. It was amazing." (Kirsten, 2018: 41)

Charlie hopes Katie can do with his music to make everyone know that Katie has a hidden talent. But Katie does not want to do so. Though Charlie feels that Katie has a sweet voice to listen to. In addition, Katie also creates her own songs. This is what makes Charlie hope that Katie can develop her talent in singing.

\subsection{Responsibility}

Being responsible means being dependable, keeping promises and honoring our commitments. It is accepting the consequences for what we say and do. It also means developing our potential. People who are responsible do not make excuses for their actions or blame others when things go wrong. As describe in chapter II in 2.4.1 part d. In the film Midnight Sun, Charlie still maintains his swimming qualities even though he has an injury and cannot participate in swimming competitions. But he still kept his technique in swimming and did not forget, it shows that Charlie is responsible for what he does.

"Are you ready? For what? To go swimming. No, Katie, you know I do not swim anymore. Yes, you do. You just have not swam in a while. And I have never swam in this water befofe, so you're gonna take me. Uh-huh. Come on! No, I'm serious. I'm not swimming. But you made me sing and I did not want to. That was totally different. No it's not! Okay, do you have any idea how cold that water is? Charlie. We could have either come all the way to the beach under the beautiful stars and not go swimming, or we could jump into that water and continue to make this best night of our lives. I do not have a swimsuit. Neither do I. Katie. You coming? Hurry up! Oh, my god. It's so cold. Put your arms forward and then push. The breast stroke? It seems like a trick. Kinda. See, this is not so bad. You do not hate the water." (Kirsten, 2018: 63-64).

The quotation above shows that Katie takes Charlie for a swim though Charlie initially refuses. In the end, Charlie agrees to swim. Katie's goal in taking Charlie swimming is to find out if Charlie still has the technical ability to swim or not. Finnaly, it turns out that Charlie still has good swimming skills. It also proves that Charlie does not hate water. In this section, Charlie teaches Katie how to swim properly. And Katie is 
sure that Charlie could win the swimming competition and get a scholarship to Berkeley.

"Go, Charlie! Push it! Go Charlie! That's it, Charlie! Come on!

Charlie, let's go! Whoo! Whoo! Go, Charlie! Come on, Charlie! Go!

Go! Whoo hoo! Yeah! Yeah!" (Kirsten, 2018: 80).

The above quotation describes the support given to Charlie who is struggling to become a winner in the competition. Charlie tries to do his best. He does not want his hard work in swimming practice to go without result. Moreover, Berkeley coach comes to see it live. So, Charlie has to show his skills and impress the Berkeley coach. Charlie thinks he should not miss the chance to get a scholarship to Berkeley.

"I've waited my whole life to feel this." (Kirsten, 2018: 88).

Katie states she enjoys sailing around the harbor with Charlie and enjoying the sunset together. Katie has an illness (XP). Someone who suffers from XP disease cannot be exposed to direct sunlight. If that happens, it will have a bad impact on the sufferer of the XP disease and it can cause death. Because XP is a rare disease. That is why Katie never goes out during the day, and at night she can go out. So Charlie keeps his word to take Katie around the harbor together and enjoy the sunset. Charlie knows Katie never does activities outside the house during the day. So this is something that Katie has been waiting to experience of how is like to be out in the sun.

\subsection{Self-esteem and Achievement}

In the film, Charlie wins the swimming competition and coach Berkeley gets impressed with him. Finally, Charlie can realize his dream to get a scholarship to Berkeley. Charlie tells Katie to do the recording. He hopes that Katie can develop her talent. And Katie's song is blowing up on YouTube.

"The berkeley coach was impressed and they promised to keep in touch. In touch is good. They will be in touch. I'm so proud of you, honey. Ahh. So good. Hey, i will be right back. Sure. Hey, Charlie. Hi. The rumors are true. Congrats. Thank you. You were great in there. Thank you for letteing Katie come. I could not have stopped her." (Kirsten, 2018: 54).

It is Charlie who wins the swimming competition and impresses the Berkeley coach. Charlie finally manages to get a scholarship to Berkeley. Charlie's efforts are not in vain. It is the support from those closest to him that makes Charlie feel excited about participating in swimming competitions and getting a scholarship to Berkeley.

"Come on. Come on. I'm so confused. What are we... what is this? It's

for you. Is this Katie? Yeah. Let's do this. No. Oh, my God, no. Katie.

Katie, yes. No, I can not. I can not. Yes, yes, yes. Yes. Yes. This is so crazy. How... did you even pay for this? Do not worry about it. Charlie, your truck money? I can not let you... katie, it's already done. Okay, you helped me figure out my dreams and now it's payback time. I can not play anymore. Then just sing." (Kirsten, 2018: 55).

The quotation above shows that Charlie rents the recording studio for Katie. Charlie feels that Katie has helped him to realize his dream by always supporting him. 
She is sure that Charlie could do it. Even though Charlie has to pay a fortune to rent the recording studio and uses the money that would actually be used to buy a new truck, Charlie did not think so.Charlie does this to repay Katie for helping her to fulfill her dream.

"[Man on radio] Coming up next, we have a song that is blowing up on YouTube with over two million views in just two weeks."

(Kirsten, 2018: 61).

It is described that Katie's song is blowing up on YouTube with over two million views just for two weeks. Charlie is so happy because he does not expect that Katie's song can be popular. Unfortunately, Katie finally is dead because Katie has step disease.

"So, how did you do it? How did you hurt yourself? It was just a freak accident. You know, I fell down some stairs and... And that is not true. That is kind of what I tell everybody. I got really drunk one night at Owne's house. And my friends dared me to jump off the roof into the pool.. and I clipped the edge with my shoulder. I'm such an idiot. I do not wanny be that guy you know?" (Kirsten, 2018: 41).

Katie asks Charlie how he gets his shoulder injuried. Then Charlie tells her why he gets the injury. Charlie feels sorry that he has accepted the challenge from his friends to jump from the roof into the pool. As a result, he becomes desperate because he could not enter the swimming competition. She realizes that her dream of getting a scholarship to Berkeley is impossible to happen. Charlie is embarrassed and he does not want to be like an idiot. Charlie proves that he is not so kind as the guy by winning a swimming competition and getting a scholarship.

"There is this huge meet coming up next month, and the Berkeley coach is coming down to watch. But I'd have to get in shape by then, which is probably impossible. And then I'd have to swim, like, my best time ever to show that I'm fully rehabbed... You can totally do it." (Kirsten, 2018: 35).

The above quotation talks about Charlie's feeling. He is desperate because there is no way to be fit before the competition starts. He has to swim as well as he could to show that he is fully recovered. Charlie was hesitant at first but katie tells him that he can totally do it. Furthermore, Charlie thinks that he should be able to win the competition so that he will not be underestimated by his friends.

\section{Conclusion}

From the analysis, there are several points to be concluded. Four internal factors of personal motivation can be found in the movie script. The factors of personal motivation includes need, hope, responsible, self-esteem and achievement. However, one internal factor cannot be found the movie. It is job satisfaction.

Needs become the first internal factor of Charlie's personal motivation. The need deals with his desire to enter a swimming competition in order to get a scholarship to Berkeley. Hope arises when Berkeley coach contacts him to enter a swimming competition because one of the other swimmers transfer out. This is his hope to take part in a swimming competition and realize his dream to get a scholarship to Berkeley. 
Then, the responsibility comes after Charlie has felt hopeless when he could not participate in the swimming competition because he sufferes an injury which causes him to have to rest completely. But it does not last long. Finally, he is contacted by the Berkeley coach for a swimming competition. Even though at first he is desperate, he still maintaines his swimming quality and still remembers his swimming technique. Last but not least, self-esteem is described when Charlie jumps from the roof into the pool and hits his shoulder against the pool wall. This causes him to injure his shoulder and is unable to participate in swimming competitions. He proves that he keeps trying to join the competition. Finally, the achievement comes after Charlie manages to impress the Berkeley coach by winning the swimming competition. In conclusion, he is able to fulfill his dream due to the internal factors coming within himself.

\section{References}

Alma, Buchari. (2013). Psikologi perkembangan dan manajemen pemasaran dan pemasaran jasa. Bandung: Alfabeta.

Cameron, J., \& Pierce, W. D. (1994). Reinforcement, Reward, and Intrinsic Motivation: A Meta-Analysis. Review of Educational Research, 64(3), 363-423. https://psycnet.apa.org/doi/10.2307/1170677

Campbell, J.P., and Pritchard, R.D. (1976). Motivation Theory in Industrial and Organizational Psychology. In M. D. Dunnette (Ed.), Handbook of Industrial and Organizational Psychology, pp. 63-130. Chicago: Rand McNally.

Creswell W. John. (2013). Research Design Pendekatan Kualitatif, Kuantitatif, dan Mixed. Yogyakarta :PustakaPelajar

Denhardt, R. B., Denhardt, J. V., \& Aristigueta, M. P. (2008). Managing Human Behavior in Public and Nonprofit Organizations. Los Angeles: Sage Publications, Inc.

Hurlock, Elizabeth B. (1980). Psikologi Perkembangan: Suatu Pendekatan Sepanjang Kehidupan. Jakarta: Erlangga, Edisikelima.

Kristen, Eric Romaro. (2018). Midnight Sun. https://www.imdb.com/name/nm5560393/news.

Latif ah, E. (2012). Pengantar Psikologi Pendidikan. Yogyakarta: Pedagogia.

Lepper, M. R., \& Hodell, M. (1989). Intrinsic Motivation in the Classroom. Research on Motivation in Education. In C. Ames and R. Ames (Eds.). Research on motivation in Education: Vol.3 Goals and Cognitions, 73-105. San Diego, CA: Academic Press.

Lili, G. And Nasution, F.K.S. (2005). Peran Pola Asuh Orang Tua dalam Motivasi Berprestasi. Psikologia, 1(1). Retrieved from https://adoc.pub/peran-pola-asuhorang-tua-dalam-motivasi-berprestasi.html

McClelland, David C. (2005). Motivation. New York: Cambridge.

Malone, T. and Lepper. (1987). Making Learning Fun: a Taxonomy of Intrinsic Motivations for Learning. In Snow, R. \& Farr, M. J. (Ed), Aptitude, Learning, and Instruction Volume 3: Conative and Affective Process Analyses. New Jersey: Hillsdale.

Mangkunegara, A.P. (2008). Pengaruh Pola Perilaku Kepemimpinan Orientasi Camprestasi terhadap Motivasi Berprestasi dan Penerapan Budaya Organisasi. Phronesis Jurnal Ilmiah PsikologiIndustri dan Organisasi, Vol. 10, No.2, 116131. 
Factors of Personal Motivation in Eric Ramiro Kirsten's Movie Script Midnight Sun, Nanda Herliana, Andang Suhendi

Maslow, A. H. (1946). Conflict, Frustration, and the Theory of Threat. J. abnorm. (soc.) Psychol., 38, 81-86.

Sadirman, A.M.. (2011). Interaksi dan Motivasi Belajar Mengajar. Jakarta: PT. Raja grafindo.

Wellek, R. and Warren, A. (2016). Teori Kesusastraan (diterjemahkan oleh Melani Budianta). Jakarta: Pustaka Jaya 